\section{SUMMARY}

A method for the biosynthesis of $\left.{ }^{14} \mathrm{C}\right]$ ergosterol from sodium [methyl $\left.-{ }^{14} \mathrm{C}\right]$ acetate in the mould Carpenteles brefeldianum Dodge is described. The specific activity of the $\left[{ }^{14} \mathrm{C}\right]$ ergosterol obtained was $0 \cdot 1-0.3 \mu \mathrm{c} / \mathrm{mg}$., and the total yield of radiocarbon was $2-6 \%$. The specific activity of the [methyl $\left.-{ }^{14} \mathrm{C}\right]$ acetate used before dilution was $38 \mu \mathrm{c} / \mathrm{mg}$.

We wish to thank the Medical Research Council for financial support.

\section{REFERENCES}

Glover, J. (1956). Moderne Methoden der Pfanzen Analyse, vol. 1, p. 325. Ed. Paech, K. \& Tracey, M. V. Berlin: Springer-Verlag.

Glover, J., Kamen, M. D. \& Genderen, H. van (1952). Arch. Biochem. Biophys. 35, 384.

Glover, J., Leat, W. M. F. \& Morton, R. A. (1954). Biochem. J. 58, xvii.
Glover, M. (1949). Ph.D. Thesis: University of Liverpool. Glover, M., Glover, J. \& Morton, R. A. (1952). Biochem. J. $51,1$.

Green, C. (1955). Ph.D. Thesis: University of Liverpool.

Hanahan, D. J. \& Al-Wakil, S. J. (1952). Arch. Biochem. Biophys. 37, 167.

Klein, H. P. (1951). Fed. Proc. 10, 209.

Klein, H. P., Eaton, N. R. \& Murphy, J. C. (1954). Biochim. biophys. Acta, 13, 591.

Kodicek, E. (1955). Biochem. J. 60, xxv.

Kodicek, E. \& Ashby, D. R. (1954). Biochem. J. 57, xii.

Moore, P. R. \& Baumann, C. A. (1952). J. biol. Chem. 195, 615.

Oxford, A. E., Raistrick, H. \& Simonart, P. (1935). Biochem. J. 29, 1102.

Schonheimer, R. \& Dam, H. (1933). Hoppe-Seyl. Z. 215, 59.

Shakir, M. K. (1948). Ph.D. Thesis: University of Liverpool.

Shaw, W. H. C. \& Jefferies, J. P. (1953). Analyst, 78, 509.

Zook, H. D., Oakwood, T. S. \& Whitmore, F. C. (1944). Science, 99, 427.

\title{
Sterol Metabolism
}

\section{THE ABSORPTION AND METABOLISM OF [14C]ERGOSTEROL IN THE GUINEA PIG}

\author{
By J. GLOVER, W. M. F. LEAT AND R. A. MORTON \\ Biochemistry Department, The University of Liverpool
}

(Received 1 October 1956)

The absorption of ergosterol has been studied in many species because its ultraviolet-absorption spectrum forms an excellent label. The early work of Schonheimer, Behring \& Gottberg (1932) on the dog and Menschick \& Page (1932) on the laying hen suggested that although the sterol was poorly absorbed, small amounts did in fact penetrate the intestine. The work of Schonheimer and coworkers (Schonheimer, 1931), on rats, rabbits and mice, of Cook (1938) on the guinea pig and of many other workers since then have, however, clearly demonstrated that phytosterols in general, including ergosterol, are poorly absorbed. The actual amounts which cross the intestine have only recently been assessed by using isotopically labelled sterols. Hanahan \& Al-Wakil (1953) showed that $4 \%$ of a single dose of $\left[{ }^{14} \mathrm{C}\right]$ ergosterol is absorbed by the rat, and Gould (1954) has shown that tritiumlabelled $\beta$-sitosterol is absorbed to the extent of $0.4 \%$. Similarly, $4 \%$ of a dose of ${ }^{14} \mathrm{C}$-labelled sterols from tomato leaves has been found to be absorbed by the guinea pig (Duncan, 1954).

The present studies on the guinea pig, which were begun some years ago, before the use of ${ }^{14} \mathrm{C}$-labelled materials, were undertaken because: $(a)$ the guinea pig, which possesses in the gut wall a high concen- tration of the analogous animal sterol, 7-dehydrocholesterol ( $\Delta^{5: 7}$-cholestadien-3 $\beta$-ol), might absorb ergosterol better than other species; if the ergosterol were hydrogenated to 7:8-dihydroergosterol(brassicasterol) or to 5:6-dihydroergosterol by the intestinal enzymes, in a manner similar to the hydrogenation of 7-dehydrocholesterol (Glover, Glover \& Morton, 1952), it would escape spectroscopic detection; (b) the different steric configuration of the side chain of ergosterol could perhaps enable it to act as an inhibitor of the sterol dehydrogenase enzyme system leading to a disturbance of the normal equilibrium obtaining there; (c) ergosterol can be labelled with ${ }^{14} \mathrm{C}$ easily so that its detailed metabolism may be studied.

A preliminary account of the work has already been published (Glover, Leat \& Morton, 1954).

\section{EXPERIMENTAL}

Materials. Crystalline ergosterol was obtained from Peboc Ltd., Liverpool. Uniformly labelled [ $\left.{ }^{14} \mathrm{C}\right]$ ergosterol was prepared biosynthetically from [methyl-14 C]acetate in the mould Carpenteles brefeldianum Dodge (Glover \& Leat, 1957).

The sterol-free diet for the guinea pigs was prepared by mixing solvent-extracted food cubes (diet no. 4, British Extracting Co. Ltd., Bromborough) with $5 \%$ of arachis oil. 
Animals. Young female guinea pigs (10 weeks' old; 230$300 \mathrm{~g}$. body wt.) were obtained direct from the breeder and placed on the cube diet no. 4 supplemented with cabbage for 5 days before selection for experiment. They were then placed on the sterol-free diet for 3-7 days before dosing. Twelve animals, divided into four groups of three, were employed in each experiment. The animals were so distributed that the average weight in each group was approximately the same. This was necessary since the ratio of 7 dehydrocholesterol to total sterol in the intestine increases with increasing weight (age) of the animal. The four groups of animals were starved for $24 \mathrm{hr}$. immediately before dosing and kept in cages with a $\frac{1}{2}$ in. mesh base to prevent coprophagy. A single dose of ergosterol $(170 \mathrm{mg}$. in $1 \mathrm{ml}$. of ethyl oleate) was administered orally to each animal from a pipette with a wide-bore tip. The animals used in a few of the experiments with $\left[{ }^{14} \mathrm{C}\right]$ ergosterol were larger $(500 \mathrm{~g}$. each), and in the more accurate quantitative work these were dosed by stomach tube. The animals were killed by a sharp blow at the back of the neck, at different time intervals of a few hours up to $24 \mathrm{hr}$. after dosing. The livers, intestines and other organs were removed and the respective tissues in each group pooled for analysis. The contents of the stomachs and intestines were flushed out with physiological saline and retained.

Extraction of tissues. Each tissue was cut into small pieces, placed in a round-bottomed flask and digested with half its weight of $60 \%$ (w/v) KOH until no solid matter remained. An equal volume of ethanol was then added and the mixture was refluxed for $45 \mathrm{~min}$. The saponified mixture was cooled and poured into a separating funnel containing 1 vol. of water and the flask was rinsed out with a second volume of water. The rinsings were added to the original solution and extracted with five portions of ether $(100 \mathrm{ml}$. each) rendered peroxide-free by drying and distilling it over reduced iron. The bulked ether extract was washed with water, until the aqueous phase showed no pink colour with phenolphthalein, and then dried over anhydrous $\mathrm{Na}_{2} \mathrm{SO}_{4}$ for $30 \mathrm{~min}$. at $5^{\circ}$. The dry ether solution was separated, the $\mathrm{Na}_{2} \mathrm{SO}_{4}$ rinsed with ether and the whole was taken to small volume in a stream of $\mathrm{N}_{2}$. The residual solution was finally transferred to a tared $25 \mathrm{ml}$. conical flask taken to dryness under $\mathrm{N}_{2}$ and the non-saponifiable residue weighed. The fatty acid fraction was obtained by acidifying the aqueous phase mentioned above with dilute $\mathrm{H}_{2} \mathrm{SO}_{4}$ to $\mathrm{pH} 1$, and extracting with five portions of ether and treating the extract as above.

To the intestinal contents was added an equal volume of ethanol to denature and precipitate proteins and the whole extracted with ether as above. In addition to the liver and intestine, the adrenals, kidney, lungs, spleen, mesentery and carcass were also examined in one experiment. Thelipids from kidney, lungs and spleen contained only small amounts of the radioisotope and consequently were pooled for analysis.

Adsorption chromatography. The liver unsaponifiable matter (approximately $100 \mathrm{mg}$.) dissolved in 15-20 ml. of $2 \%(v / v)$ diethyl ether in light petroleum (b.p. 40-60 $)$ was chromatographed on alumina (grade 0 , Spence, Widnes) deactivated with $2 \%(\mathrm{v} / \mathrm{w})$ of water, according to the procedure described by Duncan (1954). All the 7-dehydrocholesterol, together with ergosterol, was concentrated thereby in a fraction as free as possible from other selectively absorbing substances. This enabled the sterols to be assayed spectrophotometrically with accuracy.
Paper chromatography. Portions of the unsaponifiable matter of the liver and intestine were examined on Whatman paper no. 3 as described by Kodicek \& Ashby (1954). The various unsaturated sterols were detected by extracting 5-20 mm. sections of the paper with chloroform in a test tube and carrying out the Liebermann-Burchard test.

\section{Estimation of sterols}

The total sterols were determined mainly by the colorimetric method of Kenny (1952), but a number of results obtained by this method were also checked by the gravimetric digitonide procedure of Windaus (1909). The discrepancy in the results obtained by the two methods was generally less than $\pm 2 \%$. The figures for liver non-saponifiable matter by the gravimetric method tended to be higher than the colorimetric, and vice versa for the intestine, which contains a high percentage of the more intensely reacting fractions.

$\Delta^{5: 7}$-Sterols. The absorption spectra were recorded on a photoelectric spectrophotometer and the conjugated $\Delta^{5: 7}$-diene sterols estimated by the three-point correction procedure for irrelevant absorption as previously described (Glover et al. 1952).

Radioassay. The radioactivity in the lipid fractions was

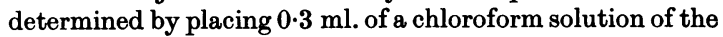
material on a flat stainless-steel planchet $(19 \mathrm{~mm}$. diam. with $3 \mathrm{~mm}$. side) over the base of which was placed a disk of lens paper (Green's no. 105). The solvent was evaporated by irradiation from above with infrared lamps ( $250 \mathrm{w})$. The lens paper ensures a uniform distribution of the lipid over the bottom of the planchet. The over-all efficiency of the Geiger-Müller counter system was $4 \%$ and the reproducibility of the plating technique less than $\pm 2 \%$ s.D. All samples were counted for sufficient time to make the counting error less than $\pm 5 \%$ and corrected for self-absorption and background.

\section{RESULTS}

Absorption. The results for total sterol and $\Delta^{5: 7}$-sterols (7-dehydrocholesterol and ergosterol) in the livers and intestines of control animals and of those examined at various times after dosing with ergosterol are given for four experiments in Tables 1 and 2 respectively. An examination of the values for the absolute amount of $\Delta^{5: 7}$-sterols in the liver shows at the outset that absorption and storage of ergosterol per se is extremely low. Similarly, the values obtained for total sterols in the dosed animals are within the range found for the controls. The appreciable drop in the sterol-ratio values, however, confirms that a little ergosterol has been absorbed unchanged. The average increase per liver in $\Delta^{5: 7}$-sterols due to ergosterol is quite small, only about $0.1 \mathrm{mg}$. $(0.05 \%$ of the dose), and the maximum only double this value (Table 1, column 4). Since there is evidence that the more unsaturated sterols are readily metabolized in liver tissue (Taylor \& Gould, 1950; Glover et al. 1952), the above figure represents only the transitory store, and the total value over the full period of absorption of the dose was probably larger. 
In the intestine the ratio for total sterols to $\Delta^{5: 7}$-sterols (Table 2) for the dosed animals shows a definite tendency to fall below that of controls, except in Expt. 2 where the change is irregular. In the latter the level of $\Delta^{5: 7}$-sterols is abnormally low in the dosed groups. Coprophagy, which is difficult to prevent, may have occurred and would upset the ratio values. The general reduction in ratio noted, however, suggests that a small amount of ergosterol was undergoing absorption, particularly since the lowest ratios were found 6-17 hr. after dosing, i.e. during the period of maximum absorption.

It was clear that the above type of balance experiment could not give a reliable quantitative

\section{Table 1. Liver sterols of the guinea pig during the absorption of ergosterol}

Each animal in the test groups was given $170 \mathrm{mg}$. of ergosterol in $1 \mathrm{ml}$. of ethyl oleate (except in Expt. 4, when the dose was $200 \mathrm{mg}$.). Weight range of animals: $230-360 \mathrm{~g}$.; the mean weight for each group in an experiment was approximately the same. Results are expressed as mg./guinea pig.

\begin{tabular}{|c|c|c|c|c|}
\hline $\begin{array}{l}\text { Expt. no. and } \\
\text { time after dosing }\end{array}$ & $\begin{array}{c}\text { Unsaponifiable } \\
\text { matter }\end{array}$ & $\begin{array}{l}\text { Total sterol } \\
\text { (A) }\end{array}$ & $\begin{array}{l}\Delta^{5: 7 \text { 7 Sterol }} \\
\text { (B) }\end{array}$ & Ratio: A/B \\
\hline \multicolumn{5}{|l|}{1} \\
\hline $\begin{array}{l}\text { Controls } \\
6 \mathrm{hr} \text {. } \\
16 \mathrm{hr} \text {. } \\
24 \mathrm{hr} \text {. }\end{array}$ & $\begin{array}{l}40 \cdot 0 \\
53 \cdot 4 \\
46 \cdot 5 \\
42 \cdot 6\end{array}$ & $\begin{array}{l}23 \cdot 8 \\
27 \cdot 2 \\
30 \cdot 8 \\
29 \cdot 9\end{array}$ & $\begin{array}{l}0 \cdot 02 \\
0 \cdot 10 \\
0 \cdot 14 \\
0 \cdot 08\end{array}$ & $\begin{array}{r}1190 \\
270 \\
220 \\
370\end{array}$ \\
\hline \multicolumn{5}{|l|}{2} \\
\hline $\begin{array}{l}\text { Controls } \\
8 \mathrm{hr} \text {. } \\
17 \mathrm{hr} \text {. } \\
23 \mathrm{hr} \text {. }\end{array}$ & $\begin{array}{l}46 \cdot 8 \\
43 \cdot 3 \\
50 \cdot 8 \\
63 \cdot 1\end{array}$ & $\begin{array}{l}21 \cdot 9 \\
30 \cdot 3 \\
30 \cdot 0 \\
38 \cdot 0\end{array}$ & $\begin{array}{l}0.02 \\
0 \cdot 05 \\
0 \cdot 14 \\
0 \cdot 10\end{array}$ & $\begin{array}{r}1100 \\
610 \\
210 \\
380\end{array}$ \\
\hline \multicolumn{5}{|l|}{3} \\
\hline $\begin{array}{l}\text { Controls } \\
8 \mathrm{hr} \text {. } \\
17 \mathrm{hr} \text {. } \\
23 \mathrm{hr} \text {. }\end{array}$ & $\begin{array}{l}49 \cdot 5 \\
47 \cdot 7 \\
40 \cdot 0 \\
36 \cdot 4\end{array}$ & $\begin{array}{l}31 \cdot 6 \\
33 \cdot 2 \\
23 \cdot 6 \\
29 \cdot 2\end{array}$ & $\begin{array}{l}0.03 \\
0.06 \\
0 \cdot 26 \\
0.09\end{array}$ & $\begin{array}{r}1020 \\
550 \\
90 \\
320\end{array}$ \\
\hline \multicolumn{5}{|l|}{4} \\
\hline $\begin{array}{l}\text { Controls } \\
17 \mathrm{hr} \text {. }\end{array}$ & $\begin{array}{l}51 \cdot 8 \\
45 \cdot 3\end{array}$ & $\begin{array}{l}19 \cdot 6 \\
20 \cdot 3\end{array}$ & $\begin{array}{l}0.02 \\
0.09\end{array}$ & $\begin{array}{l}980 \\
230\end{array}$ \\
\hline
\end{tabular}

Table 2. Intestinal sterols of the guinea pig during the absorption of ergosterol

Each animal in the test groups was given orally $170 \mathrm{mg}$. of ergosterol in $1 \mathrm{ml}$. of ethyl oleate (except in Expt. 4, when the dose was $200 \mathrm{mg}$.). Weight range of animals: $230-360 \mathrm{~g}$.; the mean weight for the animals in each group in a given experiment was approximately the same. Results are expressed as mg./guinea pig. Number of animals is given in parentheses.

\begin{tabular}{|c|c|c|c|c|c|c|}
\hline \multicolumn{2}{|c|}{$\begin{array}{l}\text { Expt. no. and } \\
\text { time after dosing } \\
1\end{array}$} & $\begin{array}{l}\text { Unsaponifiable } \\
\text { matter }\end{array}$ & $\begin{array}{l}\text { Total } \\
\text { sterol } \\
\text { (A) }\end{array}$ & $\begin{array}{l}\Delta^{5: 7} \text {. Sterol } \\
\text { (B) }\end{array}$ & $\begin{array}{l}\text { Ratio: } \\
\text { A/B }\end{array}$ & $\begin{array}{c}\text { Residual } \\
\text { ergosterol } \\
\text { in lumen }\end{array}$ \\
\hline $\begin{array}{l}\text { Controls } \\
6 \mathrm{hr} \text {. } \\
16 \mathrm{hr} \text {. } \\
24 \mathrm{hr} \text {. }\end{array}$ & $\begin{array}{l}(4) \\
(3) \\
(3) \\
(2)\end{array}$ & $\begin{array}{l}37 \cdot 6 \\
31 \cdot 9 \\
33 \cdot 5 \\
32 \cdot 0\end{array}$ & $\begin{array}{l}22 \cdot 3 \\
22 \cdot 8 \\
22 \cdot 8 \\
21 \cdot 3\end{array}$ & $\begin{array}{l}1 \cdot 80 \\
2 \cdot 77 \\
2 \cdot 33 \\
2 \cdot 18\end{array}$ & $\begin{array}{r}12 \cdot 4 \\
8 \cdot 2 \\
9 \cdot 8 \\
9 \cdot 8\end{array}$ & $\begin{array}{r}\overline{28 \cdot 0} \\
16 \cdot 2 \\
7 \cdot 2\end{array}$ \\
\hline \multicolumn{7}{|l|}{2} \\
\hline $\begin{array}{l}\text { Controls } \\
8 \mathrm{hr} \text {. } \\
17 \mathrm{hr} \text {. } \\
23 \mathrm{hr} \text {. }\end{array}$ & $\begin{array}{l}(3) \\
(3) \\
(3) \\
(2)\end{array}$ & $\begin{array}{l}35 \cdot 6 \\
38 \cdot 3 \\
32 \cdot 8 \\
41 \cdot 5\end{array}$ & $\begin{array}{l}25 \cdot 7 \\
25 \cdot 2 \\
19 \cdot 3 \\
27 \cdot 8\end{array}$ & $\begin{array}{l}1.94 \\
1 \cdot 70 \\
1 \cdot 42 \\
1 \cdot 70\end{array}$ & \begin{tabular}{l|l|}
$13 \cdot 3$ \\
$14 \cdot 8$ \\
$13 \cdot 6$ \\
$16 \cdot 3$
\end{tabular} & $\begin{array}{r}\overline{7 \cdot 0} \\
10 \cdot 0 \\
2 \cdot 5\end{array}$ \\
\hline $\begin{array}{c}3 \\
\text { Controls } \\
6 \mathrm{hr} . \\
8 \mathrm{hr} \text {. } \\
23 \mathrm{hr} \text {. }\end{array}$ & $\begin{array}{l}(3) \\
(3) \\
(3) \\
(3)\end{array}$ & $\begin{array}{l}35 \cdot 9 \\
34 \cdot 2 \\
34 \cdot 0 \\
29 \cdot 1\end{array}$ & $\begin{array}{l}23 \cdot 4 \\
22 \cdot 9 \\
20 \cdot 8 \\
21 \cdot 3\end{array}$ & $\begin{array}{l}1 \cdot 66 \\
2 \cdot 43 \\
2 \cdot 52 \\
2 \cdot 12\end{array}$ & $\begin{array}{r}14 \cdot 1 \\
9 \cdot 4 \\
8 \cdot 3 \\
10 \cdot 0\end{array}$ & $\begin{array}{r}-\overline{29 \cdot 5} \\
11 \cdot 4 \\
5 \cdot 6\end{array}$ \\
\hline \multicolumn{7}{|l|}{4} \\
\hline $\begin{array}{l}\text { Controls } \\
17 \mathrm{hr} \text {. }\end{array}$ & $\begin{array}{l}\text { (3) } \\
\text { (3) }\end{array}$ & $\begin{array}{l}28 \cdot 8 \\
38 \cdot 0\end{array}$ & $\begin{array}{l}18 \cdot 6 \\
17 \cdot 2\end{array}$ & $\begin{array}{l}1.88 \\
1.97\end{array}$ & $\begin{array}{l}9 \cdot 9 \\
8 \cdot 7\end{array}$ & - \\
\hline
\end{tabular}


measure of the degree of absorption and metabolism of ergosterol, since the absorption is so small compared with the biological variations in sterol contents of the tissues of the different groups of animals.

More critical experiments were therefore carried out with uniformly labelled $\left[{ }^{14} \mathrm{C}\right]$ ergosterol as the tracer, which also enabled the carbon skeleton of the molecule to be followed despite the formation of other metabolites.

The amounts of radioactivity appearing in the different lipid fractions from the tissues of guinea pigs dosed with various amounts of $\left[{ }^{14} \mathrm{C}\right]$ ergosterol in ethyl oleate have been estimated. One experiment was also carried out in which the ergosterol was dispersed in aqueous Tween 80 (polyoxyalkylene derivative of sorbitan mono-oleate) solution with a view to improving absorption. The results, given in Table 3, confirm that the proportion of the dose absorbed from oleate solution is quite low (approx. $1-3 \%$ ) and bears no obvious relationship to the size of the dose. In the single Expt. 8 with Tween 80 , the percentage absorption is greater than in any of the others, although the absolute amount absorbed was lower than in Expt. 4, where ethyl oleate was the carrier.

For the latter, the amounts of total sterols and of $\Delta^{5: 7}$-sterols and their ratios in the livers and intestines are given under Expt. 4 (17 hr.) in Tables 1 and 2 respectively. A comparison of the values for percentage absorption found by spectrophotometry and assay of radiocarbon may be made. The difference between test and control spectrophotometric values for $\Delta^{5: 7}$-sterols in the liver unsaponifiable matter (Table 1) shows an increase due to the absorption of $0.07 \mathrm{mg}$. of $\left[{ }^{14} \mathrm{C}\right]$ ergosterol, whereas the radioassay (Table 3 ) indicates that an amount of radioactivity equivalent to $0.34 \mathrm{mg}$. of $\left[{ }^{14} \mathrm{C}\right]$ ergosterol is present. Similarly, the radioactivity in the intestinal unsaponifiable matter is far in excess of that which can be accounted for as $\left[{ }^{14} \mathrm{C}\right]$ ergosterol; the radioassay indicates that approx. $0.9 \mathrm{mg}$. of the original material is in that fraction, whereas the spectroscopic assay gives a difference value between test and controls within the biological variation (approx. $0.1 \mathrm{mg}$.). In fact, the radioactivity of the unsaponifiable matter from all tissues in the various experiments exceeds that which corresponds with the amount of $\left[{ }^{14} \mathrm{C}\right]$ ergosterol present in the total $\Delta^{5: 7}$-sterols found there by spectroscopic assay.

The quick appearance of radioactivity in the adrenal lipids in amount comparable with that found in the liver lipids was somewhat surprising. The final uptake by the adrenals from a single dose was greater per unit weight of tissue than that by the liver.

A considerable portion (generally more than $10 \%$ ) of the total radioactivity in the intestine appears in the fatty acid fraction. Similarly, the acidic degradation products found in the liver and adrenals indicate a rapid metabolism of the absorbed sterol. These could arise as a result of oxidative attack by the tissue enzymes or by bacterial action in the lumen of the intestine. The low recovery of ergosterol from the intestinal contents, based on the spectrophotometric assay, was unexpected in view of the report by Rosenheim \& Webster (1941) that ergosterol passed through the gut largely unchanged. The disappearance of the chromophore was checked by examining the lipids isolated from the lumina of the lower intestines of the animals dosed with [14 C]ergosterol in Tween 80 solution. The lipids were dissolved in ether and extracted twice with sodium bicarbonate solution to yield acidic fraction (I, Table 4). The remaining neutral lipids were then saponified and the fatty acids (II) and unsaponifiable matter (III) isolated. The latter was fractionated in two ways. A portion $(a)$ was dissolved in ethanol and treated with digitonin to separate the $3 \beta$-OH sterols (III $a_{1}$ ), as their digitonides, from the remaining material (III $\left.a_{2}\right)$. A second portion (b)

\section{Table 3. Absorption of $\left[{ }^{14} \mathrm{C}\right]$ ergosterol in the guinea pig}

In each of Expts. 5, 6, 7 and 8, two male animals (approx. 500 g. each) were given orally the sterol dispersed in ethyl oleate (1 ml./guinea pig) except in Expt. 8, when the sterol was suspended in aqueous Tween 80 solution. In Expt. 4 three female animals (230-260 g.) were given $200 \mathrm{mg}$. of ergosterol each in $1 \mathrm{ml}$. of ethyl oleate. The respective tissues from each group of animals were pooled.

\begin{tabular}{|c|c|c|}
\hline \multicolumn{3}{|c|}{$\begin{array}{c}\text { Dose of } \\
{\left[{ }^{14} \mathrm{C}\right] \text { ergosterol } /} \\
\text { guinea pig }\end{array}$} \\
\hline $\begin{array}{c}\text { Expt. } \\
\text { no. }\end{array}$ & (mg.) & $(\mu \mathrm{C})$ \\
\hline $\begin{array}{l}5 \\
6 \\
7 \\
8\end{array}$ & $\begin{array}{c}3 \\
83 \\
85 \\
5 \cdot 5\end{array}$ & $\begin{array}{l}0 \cdot 77 \\
0 \cdot 45 \\
0 \cdot 35 \\
1 \cdot 41\end{array}$ \\
\hline 4 & 200 & 0.39 \\
\hline
\end{tabular}

$\begin{array}{ccc}\text { Time } \\ \text { examined } \\ \text { (hr.) } & \begin{array}{c}\text { Unsaponi- } \\ \text { fiable } \\ \text { matter }\end{array} & \begin{array}{c}\text { Fatty } \\ \text { acids }\end{array} \\ 6 & 0.28 & 0.06 \\ 6 & 0.33 & \text { None } \\ 17 & 0.30 & 0.03 \\ 3.5 & 2.60 & 0.63 \\ 17 & 0.46 & 1.24\end{array}$

Percentage of ${ }^{14} \mathrm{C}$ absorbed

\begin{tabular}{|c|c|c|c|c|c|}
\hline \multicolumn{2}{|c|}{ Liver } & \multicolumn{2}{|c|}{ Adrenals } & & $\begin{array}{l}\text { Radio- } \\
\text { activity }\end{array}$ \\
\hline $\begin{array}{l}\text { Unsaponi- } \\
\text { fiable } \\
\text { matter }\end{array}$ & $\begin{array}{l}\text { Fatty } \\
\text { acids }\end{array}$ & $\begin{array}{l}\text { Unsaponi- } \\
\text { fiable } \\
\text { matter }\end{array}$ & $\begin{array}{l}\text { Fatty } \\
\text { acids }\end{array}$ & Total & $\begin{array}{c}\text { from the } \\
\text { lumen } \\
(\%)\end{array}$ \\
\hline $\begin{array}{l}0.13 \\
0.58 \\
0.15 \\
0.72\end{array}$ & $\begin{array}{l}0 \cdot 26 \\
\text { None } \\
\text { None } \\
0 \cdot 77\end{array}$ & $\begin{array}{l}0.03 \\
0.03 \\
0.03 \\
0.03\end{array}$ & $\begin{array}{l}\text { None } \\
0.03 \\
0.14 \\
0.04\end{array}$ & $\begin{array}{l}0 \cdot 76 \\
0 \cdot 97 \\
0 \cdot 65 \\
4 \cdot 79\end{array}$ & $\begin{array}{l}-\overline{75} \\
50 \cdot 4 \\
73 \cdot 4\end{array}$ \\
\hline $0 \cdot 17$ & $0 \cdot 70$ & 0.32 & $0 \cdot 20$ & 3.09 & - \\
\hline
\end{tabular}

Radioecovered rom the umen

$50 \cdot 4$

$73 \cdot 4$ 
was chromatographed on alumina and three fractions were eluted with $12 \%(v / v)$ ether in light petroleum $\left(\mathrm{III} b_{1}\right)$, ether (III $\left.b_{2}\right)$ and ethanol (III $\left.b_{3}\right)$ respectively. The absorption spectrum of the sterol fraction recovered from the digitonides and that of the first fraction from the column, each of which contained all the residual ergosterol, showed in both that it was present only in trace amounts. The radioactivity in the various fractions was expressed as a percentage of the total in the original lipids, which represented $73 \%$ of the dose. The results are set out in Table 4.

None of the above fractions was examined in greater detail but the preliminary analysis makes it sufficiently clear that the ergosterol, in passing down the intestine, has been rapidly attacked. The $3 \beta-\mathrm{OH}$ group has been destroyed in approx. $50 \%$ of the material; the conjugated diene system in ring $B$ has been more extensively destroyed and some carboxylic acids were formed. This severe destruction of the ergosterol is probably an important contributory cause of the poor absorption.

\section{Unsaponifiable matter of the various tissues}

Gut wall and liver. In one experiment the unsaponifiable matter from these tissues was chromatographed on alumina as previously described to determine if any of the conjugated diene system in the administered sterol had been enzymically reduced, since there is evidence that this occurs with 7-dehydrocholesterol in the guinea pig (Glover et al. 1952; Green, 1955) and in the rat (Glover \& Stainer, 1956). The more saturated sterol fraction (including $\Delta^{5}$ - and $\Delta^{7}$-sterols) was examined and found to contain a small amount of radioactivity, but the amount (less than $1 \%$ of the total placed on the column) was not sufficient to make the result conclusive, although the previously mentioned discrepancy between total radioactivity in the, unsaponifiable matter (of liver and intestine) compared with that due to $\left[{ }^{14} \mathrm{C}\right]$ ergosterol is noteworthy.
Adrenals. In this tissue, $17 \mathrm{hr}$. after dosing, the radioactivity taken up became comparable with that in the liver (Table 3). The ultraviolet-absorption spectrum of the unsaponifiable matter did not show the characteristic absorption due to ergosterol. Most of the radioactivity in the adrenals, then, is presumed to arise from metabolites. Hanahan \& Al-Wakil (1953) and Biggs, Lemmon \& Pierce (1954) also found that radioactivity from the dietary sterols $\left[{ }^{14} \mathrm{C}\right]$ ergosterol and $\Delta^{7}-\left[{ }^{14} \mathrm{C}\right]$ cholestenol respectively appeared readily in this tissue.

Kidney, lungs, spleen and mesenteric fat. None of these organs retained an appreciable amount of the $\left.{ }^{14} \mathrm{C}\right]$ ergosterol administered.

Skin. The skin possesses such a large amount of the total body sterol, which it can manufacture de novo (Gould \& Taylor, 1950), that a small uptake of the poorly absorbed ergosterol from the blood is extensively diluted and not readily detected. In one experiment, a piece of abdominal skin 4 in. $\times 4$ in. was taken from an animal killed $23 \mathrm{hr}$. after dosing with $0.33 \mu \mathrm{C}$ of $\left[{ }^{14} \mathrm{C}\right]$ ergosterol. The extracted lipid possessed no detectable radioactivity. In order to examine how ergosterol may be metabolized by the skin, $1 \mathrm{mg}$. of [ $\left.{ }^{14} \mathrm{C}\right]$ ergosterol $(0.3 \mu \mathrm{c})$ dispersed in $0.5 \mathrm{ml}$. of aqueous Tween 80 was injected subcutaneously into an ansesthetized adult guinea pig. A week later the animal was killed and the skin around the site of injection (4 in. in area), the liver and adrenals were removed for examination. The lipids were extracted from the skin and saponified. The ether-soluble recovered fatty acids did not contain any radioactivity, and of that in the unsaponifiable matter almost all was localized in the sterol fraction precipitated with digitonin; only a trace of activity was found in the supernatant from the digitonin precipitation. Since the ultraviolet spectrum of the sterol fraction did not show appreciable absorption in the 260$310 \mathrm{~m} \mu$ region characteristic of $\Delta^{5: 7}$-sterols, the $\left[{ }^{14} \mathrm{C}\right]$ ergosterol injected must have been partly

Table 4. Percentage distribution of radioactivity in the various lipid fractions ( $\equiv 73 \%$ of dose) recovered from the lumina of the intestines of the guinea pigs dosed with $\left[{ }^{14} \mathrm{C}\right]$ ergosterol dispersed in Tween 80

Fraction

Free fatty acids (ether-soluble) (I)

Neutral lipids $\left\{\begin{array}{l}\text { ether-soluble acids (II) } \\ \text { unsaponifiable matter (III) }\end{array}\right.$
Radioactivity

(\% of total)

$\mathbf{1} \cdot \mathbf{6}$

$3 \cdot 2$

$$
\begin{aligned}
& \text { portion (b) }
\end{aligned}
$$

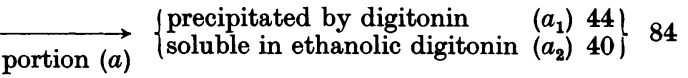


transformed into a more saturated product, which has not yet been identified. Both the liver and adrenal lipids contained radioactivity, showing that sterols can be absorbed readily from the skin.

\section{Acidic fractions}

Since radioactivity was detected in the acidic fraction of the lumen contents within a few hours after dosing with $\left[{ }^{14} \mathrm{C}\right]$ ergosterol, it was necessary to determine if the radioactivity appearing in the acidic fractions of the various tissues arose from the metabolism of their absorbed $\left[{ }^{14} \mathrm{C}\right]$ ergosterol or by absorption of the acidic material from the lumen.

The previous work of Siperstein, Jayko, Chaikoff \& Dauben (1952) with $\left.{ }^{[14} \mathrm{C}\right]$ cholesterol and of Hanahan \& Al-Wakil (1953) with $\left[{ }^{14} \mathrm{C}\right]$ ergosterol in the rat showed that bile acids are readily formed from them and excreted into the lumen. Thus part of the acidic material at least is produced in situ by the tissue enzymes. This was confirmed by preparing homogenates of liver tissue and mucosal cells and incubating them with $\left[{ }^{14} \mathrm{C}\right]$ ergosterol dispersed in aqueous Tween 80 solution. The sterol was metabolized and the acidic fractions isolated were radioactive (Leat, 1955). Full details of these results will, however, be presented in a later paper.

\section{DISCUSSION}

\section{Absorption}

The above results on absorption of ergosterol by the guinea pig agree with the findings of Hanahan \& Al-Wakil (1953) for the rat. The dispersion of the ergosterol in aqueous Tween 80 solution appears to be more effective than solution in ethyl oleate (cf. Table 3, Expts. 5 and 9) in promoting absorption, but it also caused the unabsorbed material to pass through the intestine more quickly. A high proportion of the radioactivity was recovered from the lower intestine $3.5 \mathrm{hr}$. after dosing, whereas after a similar period with ergosterol dispersed in ethyl oleate the residual material is recovered from the stomach and upper part of the small intestine. Moreover, during this time considerable destruction of the ergosterol appears to have occurred (Table 4). The carboxylic acids and other more strongly adsorbed materials probably arise by enzymic oxidation in the lumen itself. The quantity formed is too large for the various metabolites to have come from absorbed [ ${ }^{14} \mathrm{C}$ ]ergosterol metabolized and excreted via the bile. While the absorption of this phytosterol is quite low (3\% of the dose), it is significant and could conceivably be greater when ingested in a more natural form such as in yeast, where it appears to be bound as a lipoprotein which might perhaps improve dispersion or aid its stability in the lumen of the intestine. The animal sterols, cholesterol and 7-dehydrocholesterol, on the other hand, are quite readily absorbed, the former to the extent of $50 \%$ in the guinea pig (Cook, 1938). This marked difference in absorption behaviour of the two types of molecules, whose structures differ mainly in the side chain by a branched methyl group and a double bond, has caused a number of workers to study the process in detail. The high specificity of the process immediately suggests that the phenomenon is a steric one and that association with protein, possibly an enzyme, is the governing factor. Certainly the sterols cannot depend on solubility in fatty particles for their absorption, because differences in solubility are not enough to explain the observed results. The only enzyme known to be directly connected with the absorption process is an esterase, which is present in the intestine (Mueller, 1915, 1916), but phytosterols are just as readily esterified with this enzyme as is cholesterol (Swell, Field \& Treadwell, 1954). Hence it is not responsible for the poor absorption of phytosterols. Furthermore, it has been shown with deuterium-labelled esters that they are hydrolysed in the lumen for passage through the brush border and re-esterified on entering the lymphatics (Favarger \& Metzger, 1952). Free sterols, however, enter the mucosal cells without esterification (Glover \& Green, 1954), and although their subsequent removal from the cells is no doubt accelerated by this process it may not be absolutely necessary ; epicholesterol ( $3 \alpha-\mathrm{OH}$ cholesterol), which is not esterified, is absorbed at $50 \%$ of the cholesterol level and appears in thoracic chyle in the free form (Hernandez, Chaikoff, Dauben \& Abraham, 1954).

The experimental results mentioned above, and other work in this laboratory with ${ }^{14} \mathrm{C}$-labelled leaf sterols (Duncan, 1954), show quite clearly that phytosterols administered in oily solution do not in fact penetrate freely the brush-border membranes of the mucosae and become separated from their fat solvent, otherwise a much greater amount of $\left[{ }^{14} \mathrm{C}\right]$ sterol or metabolites would have accumulated in the mucosal cells. Favarger \& Roth (1953), in studying the effect of phytosterols on the digestibility of fat, also drew attention to this separation of phytosterols from their fatty supporting medium in the lumen of the intestine. Concurrently with the above studies, Glover \& Green (1954, 1956) observed in the fasting guinea pig that cholesterol and 7-dehydrocholesterol are distributed in the same equilibrium in the cell membrane, organelles and ground plasm of the intestinal mucosal cells, in which they are present as lipoproteins. Furthermore, the latter were found to exchange and transfer their sterol components between one another and with the incoming dietary sterols very rapidly. These findings, which have been confirmed recently in the rat by Glover \& Stainer (1956), led them to 
postulate that such an exchange and transfer on lipoproteins was concerned in the passage of sterols across the mucosal cells, so that absorption of sterols must occur at the molecular level. On the basis of this mechanism it is possible to provide a satisfactory explanation for the poor absorption of phytosterols. If, on account of some steric hindrance, the phytosterol does not exchange easily with the lipoproteins in the lumen (Glover \& Stainer, 1956; unpublished work) or in the mucosal cell membrane, its chance of absorption would be considerably reduced. Again, since several transfers from lipoprotein to lipoprotein may be involved in the process of crossing the cell, the blocking effect could be cumulative. Studies are now being carried out to compare the abilities of phytosterols to combine with intestinal lipoproteins with those of animal sterols and so test more fully the above suggestion. Preliminary results (Glover \& Stainer, 1956) are consistent with it.

It appears from the work of Peterson (1951) that dietary phytosterols, in addition to not being absorbed, are also capable of inhibiting the absorption of cholesterol. The original work was done on the chick and later confirmed on the rat with the aid of [4-14 C]cholesterol (Hernandez, Peterson, Chaikoff \& Dauben, 1953), but Friedman, Rosenman \& Byers (1954, 1956) have only been able to observe a slight inhibiting effect of $\beta$-sitosterol on cholesterol absorption. If, as the work of Glover \& Green (1956) suggests, sterols must be bound to proteins before absorption into the mucosal cell, then the inhibitory effect of the foreign sterol may arise from its competition with the natural animal sterol for the active adsorption centres on the acceptor lipoproteins, either within the lumen of the intestine or on the cell membrane, or in both places.

\section{Metabolism}

Lumen of the intestine. The recovery of ergosterol in the various feeding tests was always extremely poor. While a loss of 10-20\% would be reasonable to expect with the technique of oral administration by pipette, it is difficult to understand the larger losses encountered (at least $90 \%$ is not accounted for in the spectroscopic assay and about $22 \%$ by radioactivity) in the series of animals dosed with Tween 80 solution (Expt. 8). The results (Table 4) show that the recovered unsaponifiable matter from the lumen contents contained metabolites of ergosterol, a $3 \beta-\mathrm{OH}$ sterol precipitated by digitonin and also a derivative not precipitated by digitonin, both virtually transparent in the ultraviolet region of the spectrum. It was at first thought that bacteria were causing the destruction since a large portion of the dose was recovered from the lower intestine, but the recovery of $\left[{ }^{14} \mathrm{C}\right.$ ]ergosterol only $3.5 \mathrm{hr}$. after dosing was so poor that intestinal bacteria can hardly be held entirely responsible. In terms of radioactivity $2.6 \%$ of the dose was recovered from the upper intestine and stomach and had not at that time passed down the intestine far enough for appreciable bacterial metabolism to have occurred, yet less than $1 \%$ of the dose was detectable as $\left[{ }^{14} \mathrm{C}\right]$ ergosterol. The observation of Cruickshank, Kodicek \& Armitage (1955), who studied the absorption of ergocalciferol in rats previously treated with the bacteriostatic agent succinyl sulphathiazole, was very similar to that above. The ergocalciferol was destroyed just as extensively in the treated animals as in controls. It would appear that an oxidativeenzyme system within the lumen itself has caused a considerable part of the destruction observed.

At least $50 \%$ of the compound appears to suffer attack at the $3 \beta-\mathrm{OH}$ group since $44 \%$ of the recovered material is not precipitated by digitonin, and since the fraction from the column eluted with 8-12\% (v/v) ether in light petroleum is small and does not apparently contain much reduction product of the $\left[{ }^{14} \mathrm{C}\right]$ ergosterol. Perhaps ketonic compounds similar to those found by Riddell \& Cook (1955) are formed. The fact that a considerable portion of the unsaponifiable matter was more strongly adsorbed on the alumina column than ergosterol itself suggests that hydroxylated derivatives were also formed. A detailed analysis of the fractions eluted from the column was not, however, carried out, but spectrophotometric analysis revealed that the conjugated diene system had also been largely destroyed.

The acidic fraction obtained by extracting the lipids recovered from the lumen contents with sodium bicarbonate shows that a more extensive degradation of the molecule has taken place. Part of this material probably arises from ergosterol, absorbed, metabolized in the liver and excreted as a bile acid in a similar manner to the metabolism of ergosterol (Hanahan \& Al-Wakil, 1953) and cholesterol (Bloch, Berg \& Rittenberg, 1943; Bergström, 1953; Siperstein \& Chaikoff, 1952), and the remainder by metabolism in the lumen of the intestine (Edwards \& Cook, 1955).

Some acidic material labelled with ${ }^{14} \mathrm{C}$ recovered from the aqueous fraction after saponification must have been present as an ester in the contents.

Irrespective of the detailed nature of the above metabolites, it is quite clear that the absorption process has to compete quite strongly with destructive enzymes in the lumen.

Gut wall and liver. The values for $\left[{ }^{14} \mathrm{C}\right]$ ergosterol in these tissues only represent the equilibrium amounts present between the absorption and metabolic processes. They are relatively small in comparison with the bulk of animal sterol in the tissue, but if, as it appears from the work of Glover \& Green $(1954,1956)$, the dietary sterols mix readily with the 
endogenous sterols, then the rapid appearance of the ${ }^{14} \mathrm{C}$-labelled acidic fractions indicates a rapid turnover of the normal tissue sterol and is in keeping with the results of Popják \& Beeckmans (1950), who found the half-life of sterols in the intestine of the rabbit to be less than $3 \mathrm{hr}$.

Adrenals. The active manner in which this organ takes up the dietary radioactive sterol or its metabolites suggests that the adrenals, although capable of synthesizing cholesterol de novo (Gould \& Taylor, 1950), probably receive much of their sterol reserve from the blood stream. The rapid appearance of radioactivity in the fatty acid fractions implies that the tissue itself may be responsible for the degradation.

Skin. Although ingested $\left[{ }^{14} \mathrm{C}\right]$ ergosterol was transformed into a more saturated compound in skin tissue, unequivocal evidence for the reduction of ergosterol to a $\Delta^{5}$ - or $\Delta^{7}$-sterol was not obtained. Sterol dehydrogenases are probably present which can bring about the transformation of cholesterol into 7-dehydrocholesterol and lathosterol ( $\Delta^{7}$-cholestenol), all known to occur in skin tissue (Glover et al. 1952 ; Idler \& Baumann, 1953), but further work will be necessary to show if they can act on ergosterol.

The occurrence of hydrogenases catalysing the reduction of 7-dehydrocholesterol to more saturated sterols in the intestine of the guinea pig has previously been demonstrated (Glover et al. 1952). More recently, the enzymic reduction of 7-dehydrocholesterol to lathosterol has been demonstrated in the guinea-pig intestine (Green, 1955) and confirmed in that of the rat (Glover \& Stainer, 1956).

\section{SUMMARY}

1. The absorption by young female guinea pigs of ergosterol and of uniformly ${ }^{14} \mathrm{C}$-labelled material dispersed in ethyl oleate has been shown to be small but significant. Similarly, absorption of the latter dispersion by male guinea pigs is also poor, but that of a suspension of $\left[{ }^{14} \mathrm{C}\right]$ ergosterol in aqueous Tween $\mathbf{8 0}$ is a little better. A possible reason for the poor absorption is discussed.

2. The percentage absorbed was less than $0.3 \%$ estimated spectroscopically, and $0 \cdot 6-4 \cdot 8 \%$ by the assay of ${ }^{14} \mathrm{C}$ in lipid fractions of the liver, intestine and adrenals. The discrepancy in the two values obtained by the different methods arises from the active metabolism of the ingested ergosterol. Moreover, the small amounts of radioactive carbon which would normally enter the protein fractions from the labelled intermediary metabolites have not been assayed.

3. The main immediate metabolic products of ergosterol found in the intestine, liver and adrenals are acidic in nature. Some of these, however, may arise by oxidative attack in the intestine.
4. The uptake of radioactivity by the adrenals $17 \mathrm{hr}$. after dosing was as high as that by the liver, indicating that they play an important role in the metabolism of dietary ergosterol.

We wish to thank the Medical Research Council for financial support.

\section{REFERENCES}

Bergström, S. (1953). 1st Int. Colloq. Biochem. Problemen Lipiden, Brussels, p. 240.

Biggs, M. W., Lemmon, R. H. \& Pierce, F. T. (1954). Arch. Biochem. Biophys. 51, 155.

Bloch, K., Berg, B. N. \& Rittenberg, D. (1943). J.biol.Chem. 149, 511.

Cook, R. P. (1938). Biochem. J. 32, 1191.

Cruickshank, E. M., Kodicek, E. \& Armitage, P. (1955). Abstr. 3rd Int. Congr. Biochem., Brussels, p. 113.

Duncan, A. M. (1954). M.Sc. Thesis: University of Liverpool.

Edwards, D. C. \& Cook, R. P. (1955). Biochem. J. 61, 671.

Favarger, P. \& Metzger, E. F. (1952). Helv. chim. acta, 35, 1811.

Favarger, P. \& Roth, M. (1953). 1st Int. Colloq. Biochem. Problemen Lipiden, Brussels, p. 191.

Friedman, M., Rosenman, R. H. \& Byers, M. W. (1954). Circulation Res. 2, 160.

Friedman, M., Rosenman, R. H. \& Byers, M. W. (1956). Circulation Res. 4, 157.

Glover, J. \& Green, C. (1954). Biochem. J. 58, xviii.

Glover, J. \& Green, C. (1956). In Biochemical Problems of Lipids, p. 359. Ed. by Popják, G. \& Lebreton, E. London: Butterworths Scientific Publications.

Glover, J. \& Leat, W. M. F. (1957). Biochem. J. 66, 209.

Glover, J., Leat, W. M. F. \& Morton, R. A. (1954). Biochem. J. 58, xvii.

Glover, J. \& Stainer, D. W. (1956). Biochem. J. 64, $15 P$.

Glover, M., Glover, J. \& Morton, R. A. (1952). Biochem. J. $51,1$.

Gould, R. G. (1954). Circulation, 10, 589.

Gould, R. G. \& Taylor, C. B. (1950). Fed. Proc. 9, 179.

Green, C. (1955). Ph.D. Thesis: University of Liverpool.

Hanahan, D. J. \& Al-Wakil, S. J. (1953). Arch. Biochem. Biophys. 44, 150.

Hernandez, H. H., Chaikoff, I. L., Dauben, W. G. \& Abraham, S. (1954). J. biol. Chem. 206, 751.

Hernandez, H. H., Peterson, D. W., Chaikoff, I. L. \& Dauben, W. G. (1953). Proc. Soc. exp. Biol., N.Y., 83, 498.

Idler, D. R. \& Baumann, C. A. (1953). J. biol. Chem. 195, 623.

Kenny, A. P. (1952). Biochem. J. 52, 611.

Kodicek, E. \& Ashby, D. R. (1954). Biochem. J. 57, xii.

Leat, W. M. F. (1955). Ph.D. Thesis: University of Liverpool.

Menschick, W. \& Page, I. H. (1932). Hoppe-Seyl. Z. 211, 246.

Mueller, J. H. (1915). J. biol. Chem. 22, 1.

Mueller, J. H. (1916). J. biol. Chem. 27, 463. 
Peterson, D. W. (1951). Proc. Soc. exp. Biol., N. Y., 78, 143. Popják, G. \& Beeckmans, M.-L. (1950). Biochem. J. 47, 233. Riddell, C. \& Cook, R. P. (1955). Biochem. J. 61, 657.

Rosenheim, O. \& Webster, T. A. (1941). Biochem. J. 35, 920, 928 .

Schonheimer, R. (1931). Science, 74, 579.

Schonheimer, R., Behring, H. v. \& Gottberg, K. (1932). Hoppe-Seyl. Z. 208, 77.
Siperstein, M. D. \& Chaikoff, I. L. (1952). J. biol. Chem. 198, 93.

Siperstein, M. D., Jayko, M. E., Chaikoff, I. L. \& Dauben, W. G. (1952). Proc. Soc. exp. Biol., N.Y., 81, 720.

Swell, L., Field, H. \& Treadwell, C. R. (1954). Proc. Soc. exp. Biol., N.Y., 87, 216.

Taylor, C. B. \& Gould, R. G. (1950). Circulation, 2, 467.

Windaus, A. (1909). Ber. dtsch. chem. Ges. 42, 238.

\title{
Incorporation of Glycine into Glutathione and Fibrinogen of Rats under Adrenaline Treatment
}

\author{
By S. B. HENRIQUES, OLGA B. HENRIQUES AND FAJGA R. MANDELBAUM \\ Instituto Butantan, C.P. 65, S. Paulo, Brazil
}

(Received 17 September 1956)

Subcutaneous injections of adrenaline cause in the rat an increase in the concentration of plasma fibrinogen (Henriques, Henriques \& Mattos, 1950). This effect seems to be specific for adrenaline, since other sympathomimetic amines and their derivatives, administered in the same dose, cause a much lower increase in fibrinogen concentration, or have no effect at all (Henriques, Henriques \& Levy, 1956). In the present work an attempt has been made to elucidate whether the adrenaline-induced increase in fibrinogen is produced by a simple liberation of the protein from its possible stores or is caused by a more direct action of adrenaline on the metabolism of fibrinogen by stimulating its synthesis. For this purpose the specific radioactivity of glycine isolated from fibrinogen of rats treated with adrenaline was compared with that of controls injected with an equal volume of saline at various times after administration of $\left[\alpha-{ }^{14} \mathrm{C}\right]$ glycine, the concentration of fibrinogen being determined at the same time. To control the specificity of the action of adrenaline on fibrinogen, the incorporation of labelled glycine into the mixed serum proteins was determined simultaneously. As there is the possibility that liver glutathione plays some role in protein synthesis, the incorporation of labelled glycine into this tripeptide under adrenaline treatment was also studied. In connexion with this the concentration of glutathione in the liver of rats was also determined at different times after adrenaline injection.

\section{METHODS}

General. Female albino rats (96), weighing 150-180 g., were divided at random into 12 groups of 8 rats each, and used in the incorporation experiments. Half of these rats received subcutaneously $1 \mu \mathrm{g}$. of adrenaline/g. of body wt. in $0 \cdot 1-0 \cdot 3 \mathrm{ml}$. of solution, and the other half received the same volume of saline. All the animals were fasted after these injections, which were done alternately, one rat receiving adrenaline and the other saline $5 \mathrm{~min}$. later, in order to reduce the differences caused by the conditions of the animals and to allow accurate timing of the subsequent glycine injection and killing. Two hours after the adrenaline or the saline treatment each rat was injected intravenously, through a tail vein, with $2.5 \mu \mathrm{C}$ of $\left[\alpha^{-14} \mathrm{C}\right]$ glycine $(0.12 \mathrm{mg}$. dissolved in $0.125 \mathrm{ml}$. of $0.85 \% \mathrm{NaCl}) / 100 \mathrm{~g}$. of body wt. Exactly $10 \mathrm{~min}$., $20 \mathrm{~min}$. and 1, 2, 3 and $4 \mathrm{hr}$. respectively after glycine injection, the animals were bled from the aorta under anaesthesia (pentobarbitone sodium, $4 \mathrm{mg}$./ $100 \mathrm{~g}$. of body wt.) and their livers were quickly removed, sliced, pressed against blotting paper and frozen in dry ice. Equal weights (usually $5 \mathrm{~g}$.) of liver from each rat from the same group were pooled, finely pulverized in a mortar while frozen by dry ice, and immediately extracted with a solution of trichloroacetic acid (TCA) in the manner subsequently described. The blood was collected with a syringe coated with silicone, Dry Film 9987 (General Electric Co., Pittsfield, Mass., U.S.A.), and clotting was prevented by the addition of $0.01 \mathrm{ml}$. of $30 \%(\mathrm{w} / \mathrm{v})$ potassium oxalate $/ \mathrm{ml}$. of blood.

Twenty female albino rats, weighing 210-225 g., were divided at random into 4 groups of 5 rats each, and used for investigating the influence of adrenaline on the concentration of liver glutathione (GSH). The animals of group 1 received no treatment and served as controls, whereas those of groups $2-4$ received subcutaneously $1 \mu \mathrm{g}$. of adrenaline/ 100 g. of body wt. At 60, 150 and 250 min. after adrenaline injection the animals of groups 2-4 respectively were killed, under anaesthesia as previously described, by section of the inferior vena cava between the liver and the heart, the liver being removed after pressing out most of its blood. The controls were killed in the same way. A portion (l g.) of the liver was extracted in a Potter homogenizer for a few minutes with 4 vol. of $0 \cdot 14 \mathrm{~N}$-sulphosalicylic acid. The extract obtained was centrifuged and the clear supernatant was kept frozen until the determination of GSH, which took place at most $24 \mathrm{hr}$. later.

Estimation and isolation of fibrinogen. Plasma $(0.5 \mathrm{ml}$.) from each rat was used for the determination of fibrinogen by the technique of Cullen \& Van Slyke (1920) with ashing by the method of Campbell \& Hanna (1937), distillation and titration of ammonia. The rest of the plasma was used for the isolation of fibrinogen as fibrin, also by the technique of 